\title{
The Research of the Effect of High Fe Content on AISi9NiCuMg0.5 Alloy
}

\author{
Štefan Michna, Iryna Hren, Jaroslava Svobodová \\ Faculty of Mechanical Engineering, University of J. E. Purkyně in Ústí nad Labem, Pasteurova 7, 40096 Ústí nad Labem. \\ Czech Republic.E-mail: stefan.michna@ujep.cz, iryna.hren@ujep.cz, jaroslava.svobodova@ujep.cz
}

\begin{abstract}
The aim of the research on the newly developed eutectic silumin type AlSi9NiCuMg0.5, developed and patented by a team of staff of the Faculty of Mechanical Engineering, was to determine the cause of the cracking of castings under operating conditions. When the technology was put into practice, the casting was cast and then used to break the entire casting section and create a crack that crosses the whole cross section. Castings were cast by low-pressure die casting technology, where the mold is fed into the mold cavity via a cast iron tube. The essence of the research was to perform a fractographic analysis of the fracture area, to identify the structure of the casting, to identify the structural components on the surface of the fracture surface by EDS analysis on an electron scanning microscope and to determine the chemical composition of the material in the area of refraction compared to the declared alloy. From these results we can clearly identify the cause of premature cracking of castings from the newly developed eutectic silumin. Additionally, material analyzes have been carried out to see if the material has been contaminated with iron, for example by dissolving a cast-iron filler tube or a batch material. From all the analyzes and fractographic investigations carried out, it can be stated that the initiator of crack insertion and the subsequent cracking of the casting under load is the high content of rough fragments of the fractured intermetallic phases of the $\mathrm{Al}_{5} \mathrm{FeSi}$ type on the fracture surface (over $20 \%$ ), which are subject to fission. The high iron content was due to the dissolution of the cast iron ascension tube by low-pressure casting.
\end{abstract}

Keywords: Eutectic Silumin, Fractographic Analysis, EDS Analysis, Structure, Low Pressure Casting, Iron Contamination, Intermetallic Phase $\mathrm{Al}_{5} \mathrm{FeSi}$

\section{Introduction}

Aluminum-based alloys are widely used in machine building, aircraft construction, in building structures and other industries. They are also one of the most common foundry alloys. As is known, the alloys of the Al-Si system contain a lot of eutectics and therefore have high casting properties, and castings are more dense. However, like other alloys, they contain impurities that decline their properties. The constant element we always find in aluminum and its alloys is iron.

There are two main ways of getting iron into the melt. The first way is that liquid aluminum can dissolve iron from unprotected steel tools and furnace equipment, as well as with long exposure time. The second way is to get iron into the aluminum melt through the addition of lowpurity alloying materials. The iron level rises with each re-melting cycle. Iron interacts with aluminum, forming intermetallic phases of various types. This is achieved in a variety of ways by mixing iron or steel tools used in the melting and casting process, dissolving the steel or cast iron parts of the apparatus, contaminating the batch with iron ready for melting, etc. Iron is therefore found in aluminum alloys mostly as impurities, but also as alloying elements. If the iron is an alloying element, its aluminum alloy content usually does not exceed 1.0 weight percent. Iron in the form of an alloying element improves the strength properties of aluminum alloys at higher temperatures and increases its hardness to the detriment of a considerable reduction in elongation. Iron primarily reduces corrosion resistance, can cause point corrosion, reduces thermal and electrical conductivity in aluminum alloys [1, 2]. Because iron has low solubility in aluminum alloys, it is eliminated in the form of intermetallic phases, such as $\mathrm{FeAl}_{6}, \mathrm{FeAl}_{3}, \mathrm{Fe}_{2} \mathrm{SiAl}_{8}, \mathrm{AlFeMnSi}$ and $\mathrm{Al}_{5} \mathrm{FeSi}$. Iron- containing intermetallic phases are differ in their prevailing form. For example, the $\beta$-phase is formed in the form of plates. The $\alpha$-phase allocations have a complex spatial structure, looking on the sections, like Chinese letter. The so-called $\pi$-phase also forms like Chinese letter and is often, but not always, closely related to the $\beta$-phase. Intermetallic particles of this shape (especially lamellar) adversely affect the mechanical and casting properties of aluminum alloys, reduce their ductility and increase porosity.

At an iron content above $0.6 \%$, the formation of fragile phases of type $\mathrm{Al}_{5} \mathrm{FeSi}$, which are excreted in the subeutetic silumines in the interdentric spaces (Fig. 1), begin to prevail and substantially reduce the plastic properties of the material $[3,4,5]$.

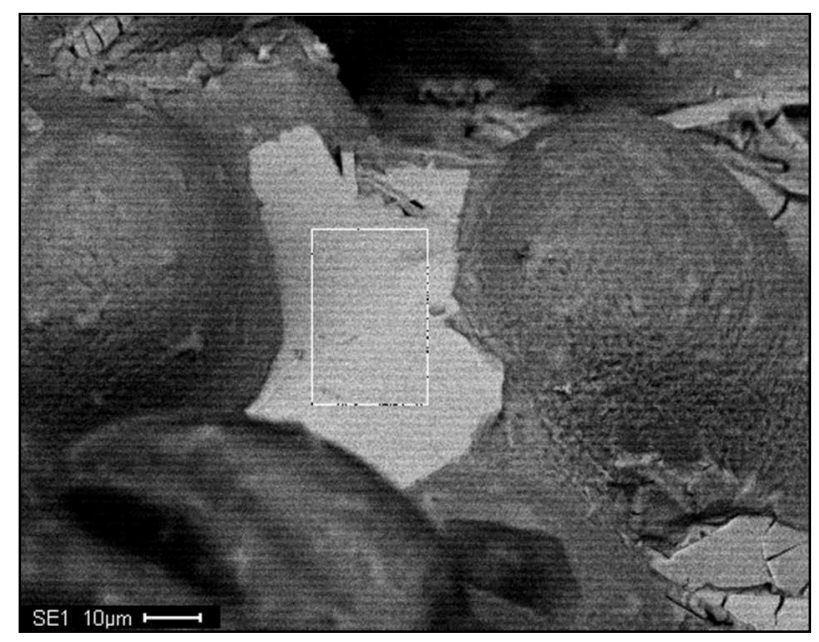

Fig. 1 Interdental areas of the AA 4032

(AlSi12NiMgCu) alloy filled with Al5FeSi coarse phase, where the Fe content is $0.82 \mathrm{wt}$. \% 


\section{Experiment}

Under the operating conditions, an alloy of $\mathrm{AlSi} 9 \mathrm{NiCuMg} 0.5$ eutectic silumin was developed and patented by a team of engineers of the Faculty of Mechanical Engineering for low-pressure casting technology to improve handling and achieve higher heat resistance (up to $200^{\circ} \mathrm{C}$ ) for the resulting castings. The chemical composition of the patented alloy is shown in Tab. 1. The batch was prepared from purchased nailed rolls, is about
$60 \%$ of batch volume and the residue was reversible waste already carries a high iron content of the previous heats. After melting the batch, the alloy was treated with a refining salt and refined with argon for $5 \mathrm{~min}$. Argon refining was carried out with a strontium modification in the form of wire. It is followed by pouring at a temperature of $745^{\circ} \mathrm{C}$ on a low pressure die casting plant at a pressure of $0.3 \mathrm{MPa}$, where the riser is made of cast iron.

Tab. 1 The chemical composition of AlSi9NiCuMg0.5 alloy

\begin{tabular}{|c|c|c|c|c|c|c|c|c|c|}
\hline \multicolumn{10}{|c|}{ Chemical composition [wt. \%] } \\
\hline Si & $\mathbf{F e}$ & $\mathbf{C u}$ & $\mathbf{M n}$ & $\mathbf{M g}$ & $\mathbf{C r}$ & $\mathbf{Z n}$ & $\mathbf{S r}$ & $\mathbf{T i}$ & $\mathbf{A l}$ \\
\hline \multirow{2}{*}{$8.5-10.0$} & max. & $0.6-1.0$ & $\begin{array}{c}\max . \\
0.6\end{array}$ & $0.4-0.8$ & $\max$. & $\max$. & $0.02-0.05$ & max. 0.15 & residue \\
\hline
\end{tabular}

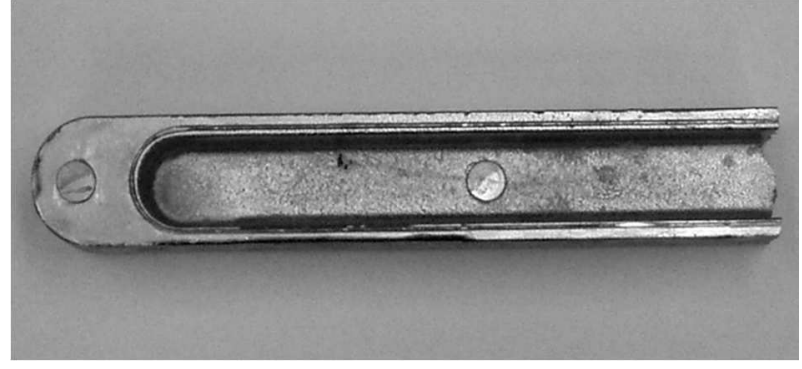

Fig. 2 Part of cast with crack

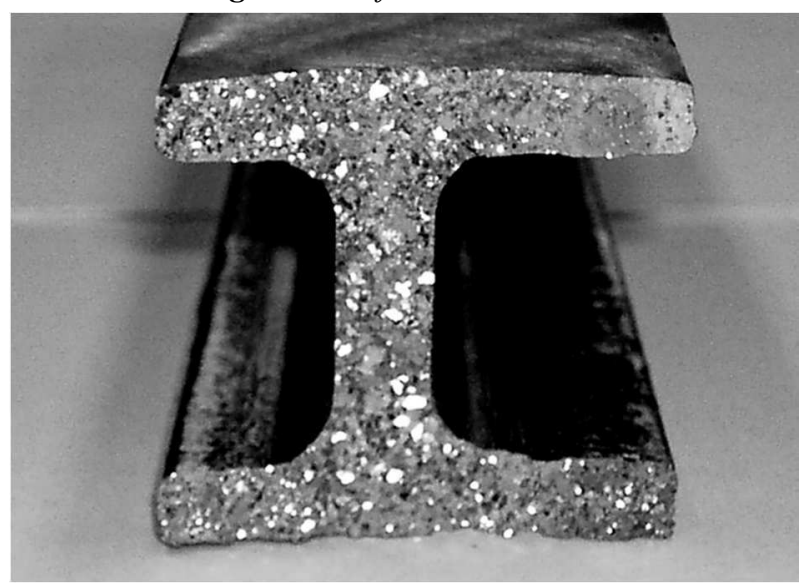

Fig. 3 Total casting surface, mag. $3 x$

When casting was applied, they were cracked in the entire cross section (Fig. 2). On the overall fracture area of the casting are visible glossy surfaces which take about $20 \%$ of the fracture area (Fig. 3).

Spectral chemical analysis of the casting was performed on the Q4 TASMAN optical emission spectrometer, which is designed for analysis of almost all metallic materials. For the casting, 5 measurements were taken at the quarry sites, from which the average value was determined for the individual elements as shown in Tab. 2. Compared to the desired composition, the chemical composition of the casting in the refractory area shows a high iron content (2.32 wt.\%), which is unacceptable in terms of its negative influence on the mechanical and chemical properties of the alloy. For all other elements, the chemical composition corresponds to the required composition of the patented AlSi9NiCuMg0.5 alloy listed in Tab. 1. In terms of the desired chemical composition, it is a polycomponent aluminum alloy type AlSi9NiCuMg0.5, which is linked to several elements. The basic alloying element is silicon, nickel, copper and magnesium. As a further element, strontium is added, which acts as a modifier. The main doping element is iron with a content up to max. $0.7 \%$, where the actual alloy exceeds its content locally almost three times.

Tab. 2 The chemical composition of AlSi9NiCuMg0.5 alloy

\begin{tabular}{|c|c|c|c|c|c|c|c|c|c|}
\hline \multicolumn{10}{|c|}{ Chemical composition [wt. \%] } \\
\hline $\mathbf{S i}$ & $\mathbf{F e}$ & $\mathbf{C u}$ & $\mathbf{M n}$ & $\mathbf{M g}$ & $\mathbf{C r}$ & $\mathbf{Z n}$ & $\mathbf{S r}$ & $\mathbf{T i}$ & $\mathbf{A l}$ \\
\hline 9.23 & 2.32 & 0.64 & 0.42 & 0.51 & 0.13 & 0.023 & 0.02 & 0.063 & residue \\
\hline
\end{tabular}

\section{Microscopic Structure Assessment}

The confocal laser microscope Olympus LEXT OLS 3100 was used to examine the microstructure of the samples. From the point of view of the finall evaluation structures in the area contiguous to the quarry we can say that this is a eutectic silumin with a plurality of individual types of structural components. The basic components of the microstructure are $\alpha$-solid solution and silicon in the form of finer and coarser hexagonal plates, which appear in the plane of the metallographic screen as sharp or partially rounded irregular needles of different sizes in the range of $10-40 \mu \mathrm{m}$ (Fig. 4). This suggests that the shape of the eutectic silicon ejected begins to change from plate to rod-shaped or fibrous, where the strontium content of silicon is insufficient. In addition, because of the high iron content, the coarse intermetallic phases of the $\mathrm{Al}_{5} \mathrm{FeSi}$ type, approximately 160 - $400 \mu \mathrm{m}$ (Fig. 4, 6), are visible in the structure. Part of the intermetallic phases of the $\mathrm{Al}_{5} \mathrm{FeSi}$ type are also excluded in the form of irregular needle-like compact shapes Fig. 6, 7). In the 
microstructure there are present branched intermetallic phases of AlFeSiMn ype Chinese script in size from 100 to $300 \mu \mathrm{m}$ (Fig. 5). The fracture microstructure microstructure in the region of the fracture shows a fractured break of frail intermetallic phases of the $\mathrm{Al}_{5} \mathrm{FeSi}$ type, which initiated the material breakdown (Fig. 8, 9, 10,11 - indicated by an arrow).

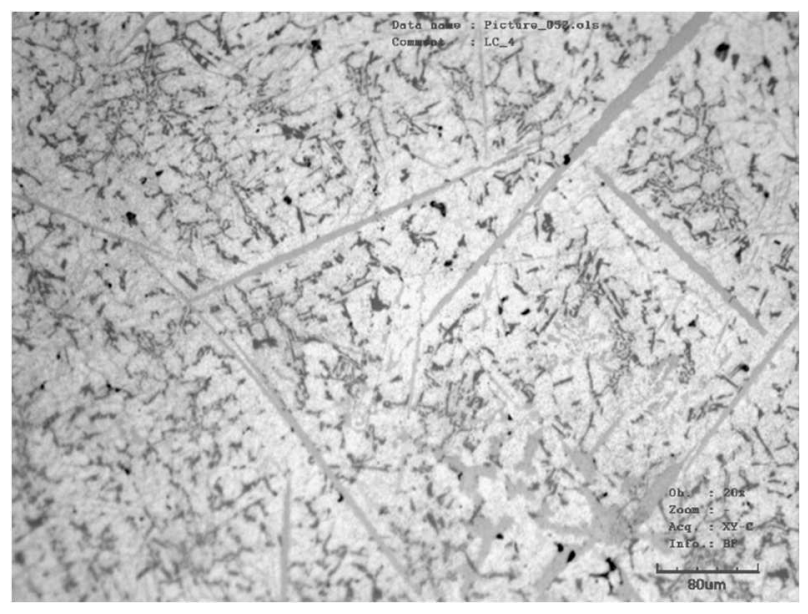

Fig. 4 AlSi9NiCuMgO.5 alloy microstructure and brittle intermetallic phases of the $\mathrm{Al}_{5} \mathrm{FeSi}$ type

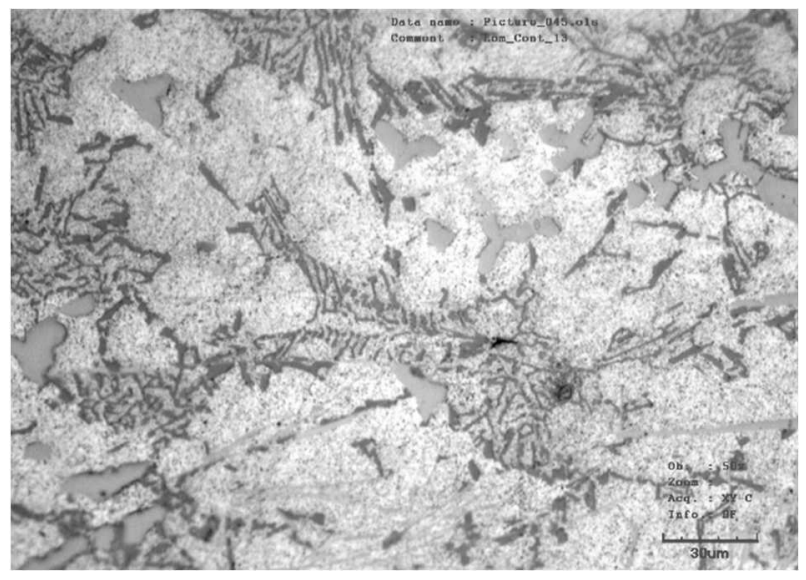

Fig. 5 Area of intermetallic phases of the «sludge phase»

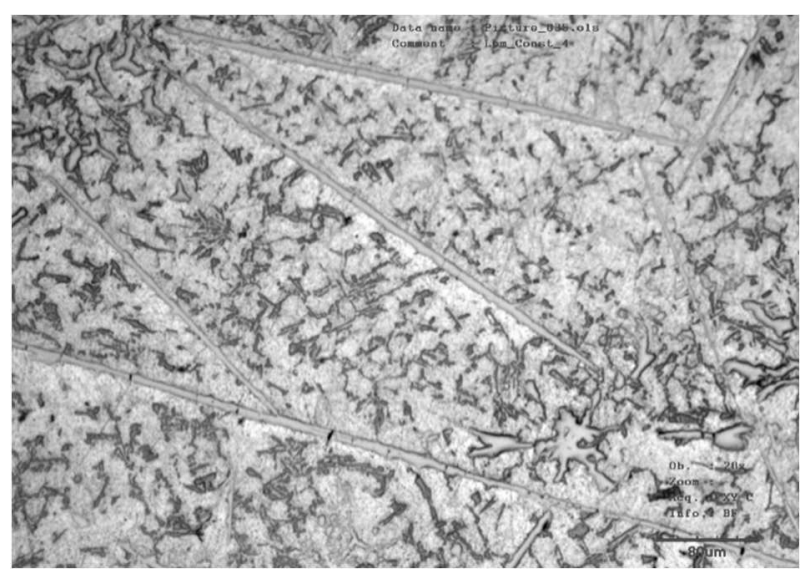

Fig. 6 Fragile intermetallic phases of type $\mathrm{Al}_{5} \mathrm{FeSi}$

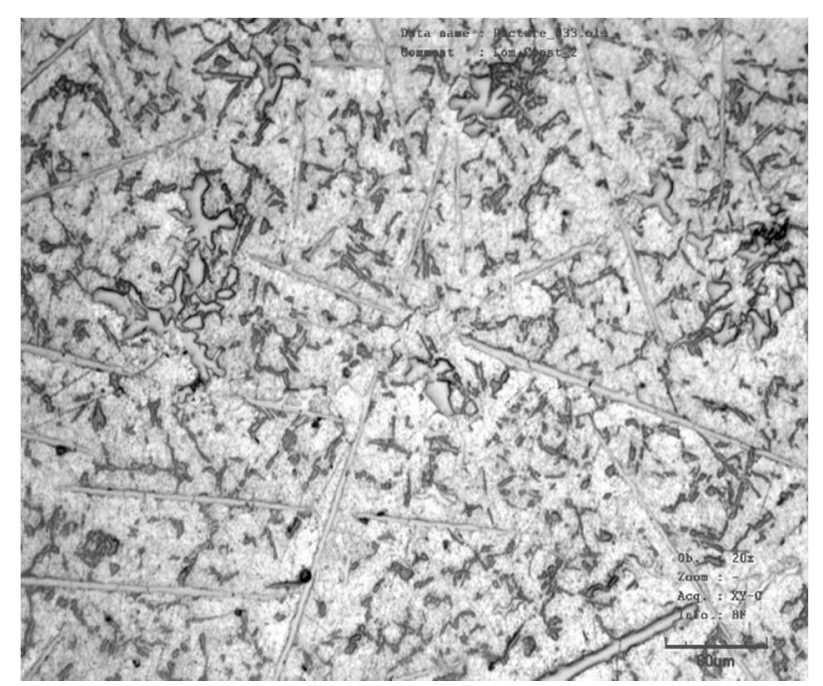

Fig. 7 Fragile intermetallic phases of type $\mathrm{Al}_{5} \mathrm{FeSi}$

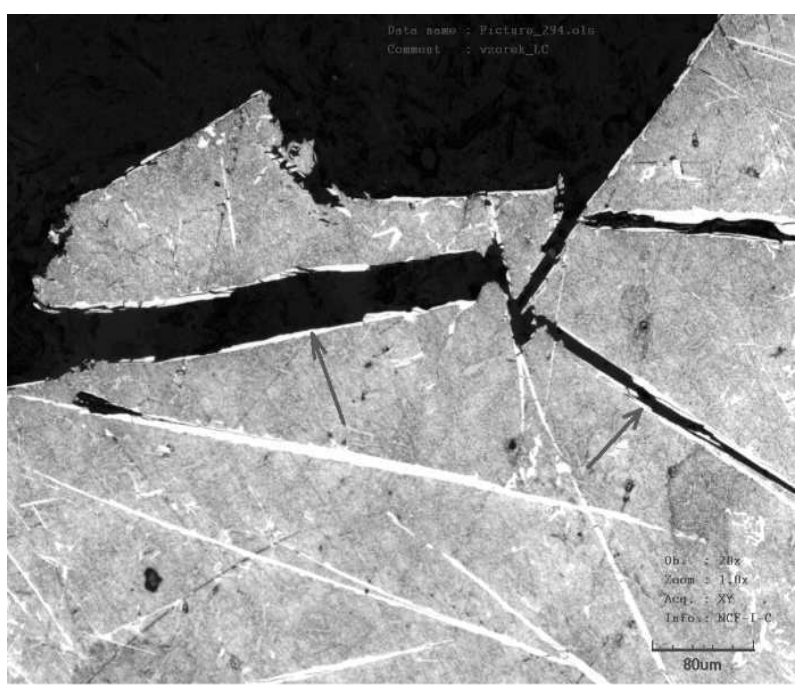

Fig. 8 Fragmentation area with fractal breakdown of intermetallic phases $\mathrm{Al}_{5} \mathrm{FeSi}$

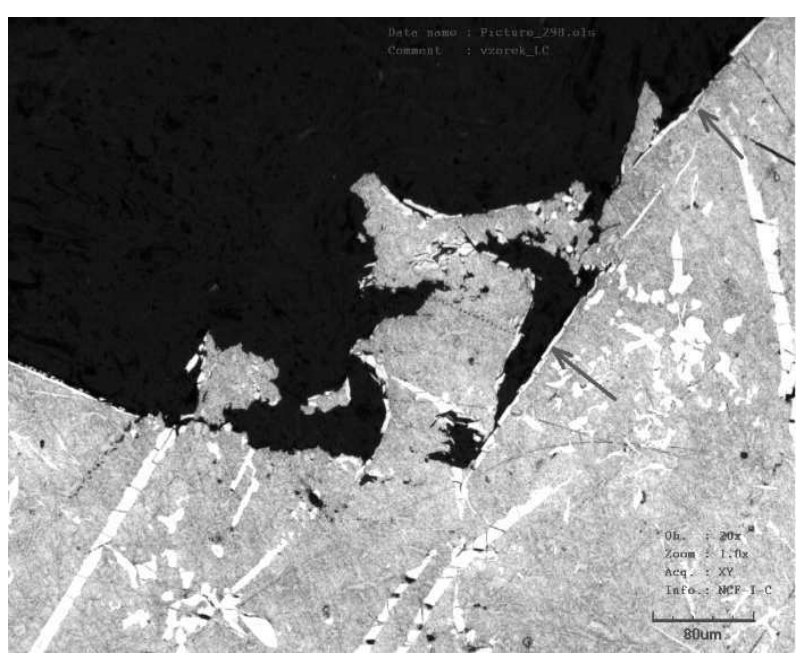

Fig. 9 Fragmentation area with fractal decomposition of intermetallic phases $\mathrm{Al}_{5} \mathrm{FeSi}$ 


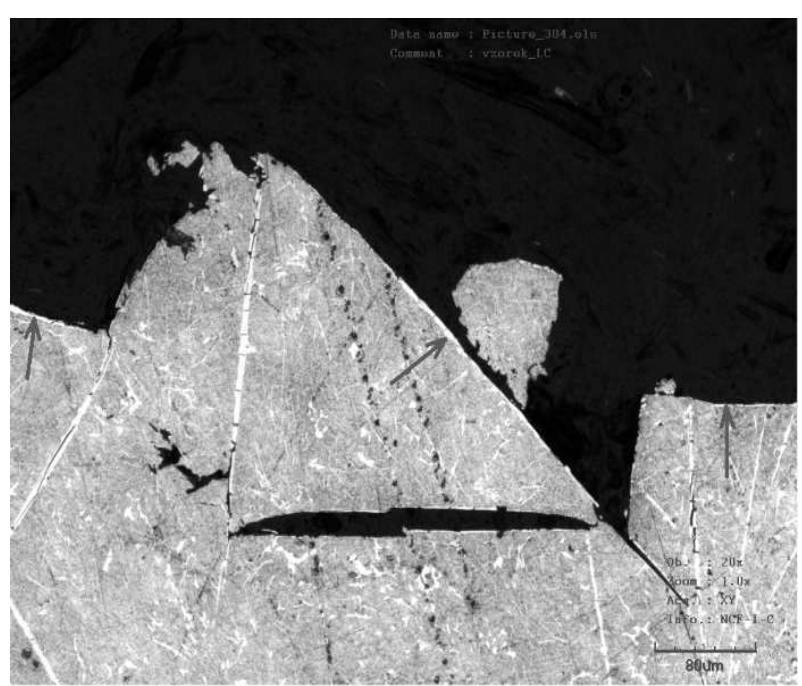

Fig. 10 Fragmentation area with fractal breakdown of intermetallic phases $\mathrm{Al}_{5} \mathrm{FeS}$

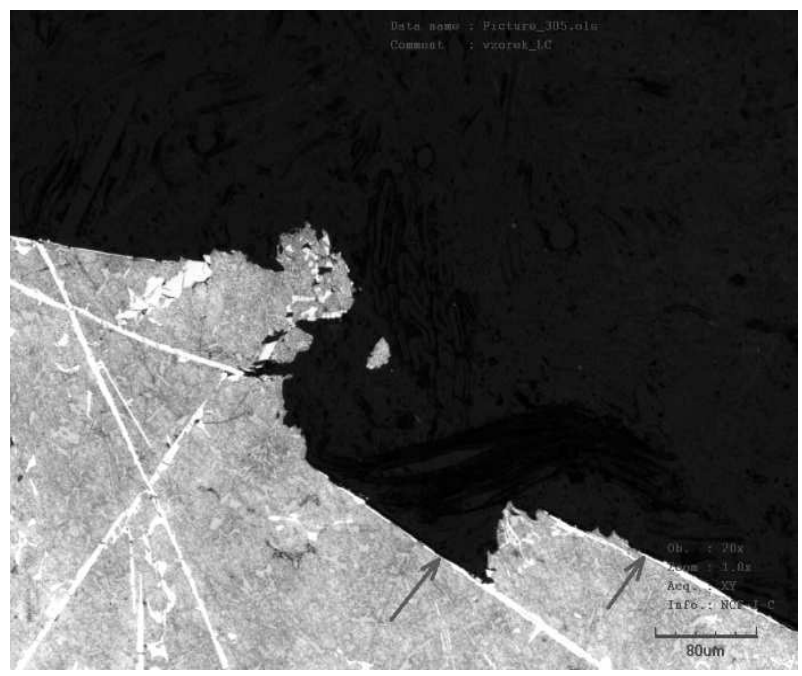

Fig. 11 Fragmentation area with fractal decomposition of intermetallic phases $\mathrm{Al}_{5} \mathrm{FeSi}$

\section{Fractographic analysis of the fracture area}

Fractographic analysis of fracture surface and EDS analysis of selected location were carried out on a scanning electron microscope. On the fracture area where observe the occurrence of cleavage fracture and transcrystalline ductile fracture (Fig. 12). The surface EDS analysis of light glossy surfaces shows the presence of $\mathrm{Al}, \mathrm{Fe}$ and $\mathrm{Si}$, where the stoichiometric ratio can be inferred that these are fragile intermetallic phases of type $\mathrm{Al}_{5} \mathrm{FeSi}$. A large number of these fragile intermetallic phases on the fracture area initiate the presence of cleavage faces in the fracture area and cause total cracking and crack propagation over the whole cross section of the casting.

\section{Location № 1}

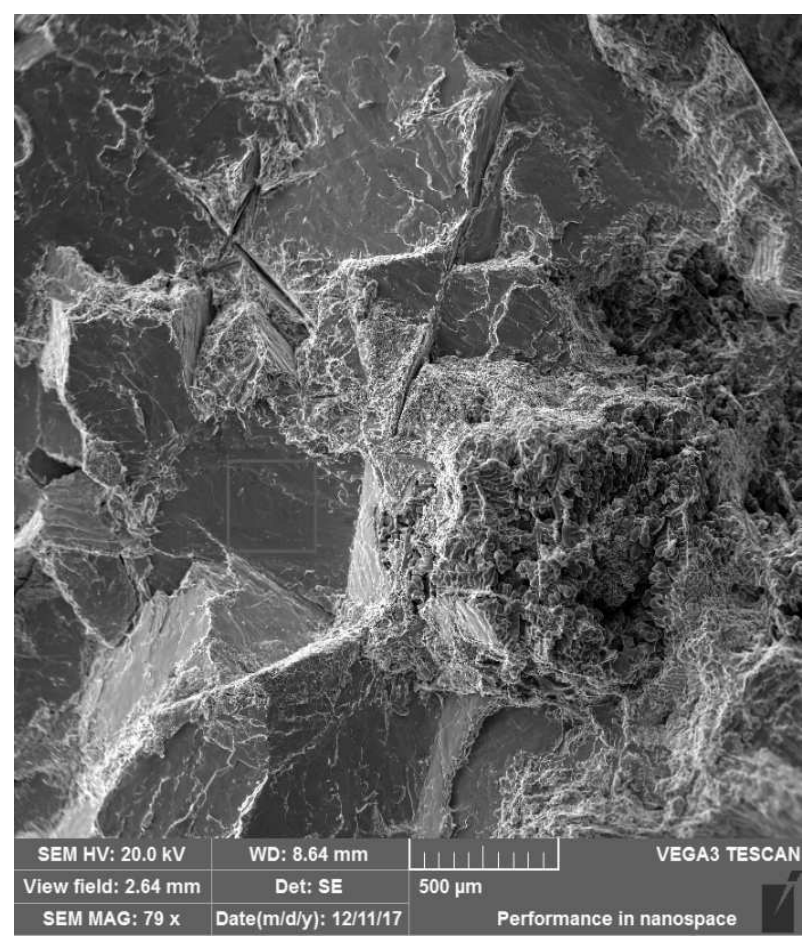

Fig. 12 Surface analysis of the sample

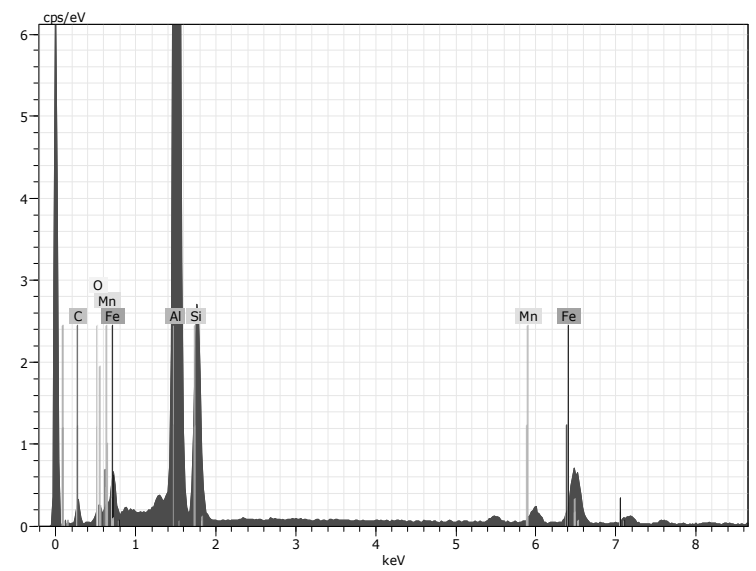

Fig. 13 The spectrum of analyzed chemical elements of the area EDS analysis (area in Fig. 12)

Tab. 3 Quantification of field EDS analysis results

\begin{tabular}{|c|c|c|c|c|c|}
\hline Element & Series & unn. C [wt. \%] & norm. C [wt.\%] & Atom. C [at. \%] & (3 Sigma) [wt. \%] \\
\hline Aluminium & K-series & 41.97 & 65.83 & 74.04 & 6.12 \\
\hline Iron & K-series & 10.32 & 16.19 & 8.80 & 1.00 \\
\hline Silicon & K-series & 8.72 & 13.68 & 14.79 & 1.24 \\
\hline Manganese & K-series & 2.74 & 4.29 & 2.37 & 0.37 \\
\hline & Total: & 63.76 & 100.00 & 100.00 & \\
\hline
\end{tabular}




\section{Location № 2}

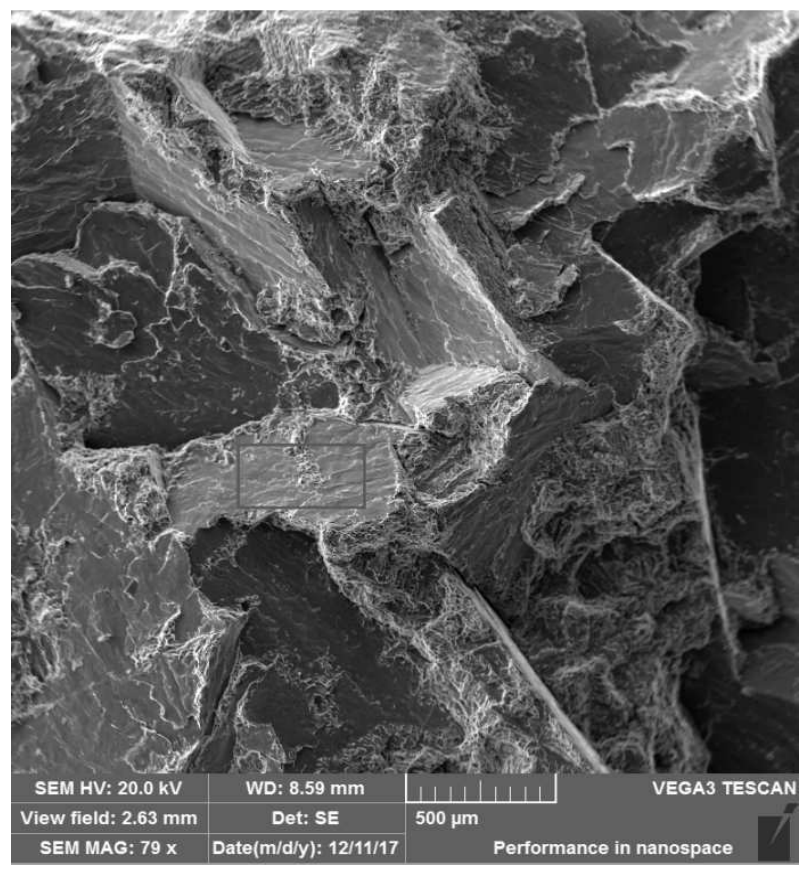

Fig. 14 Surface analysis of the sample

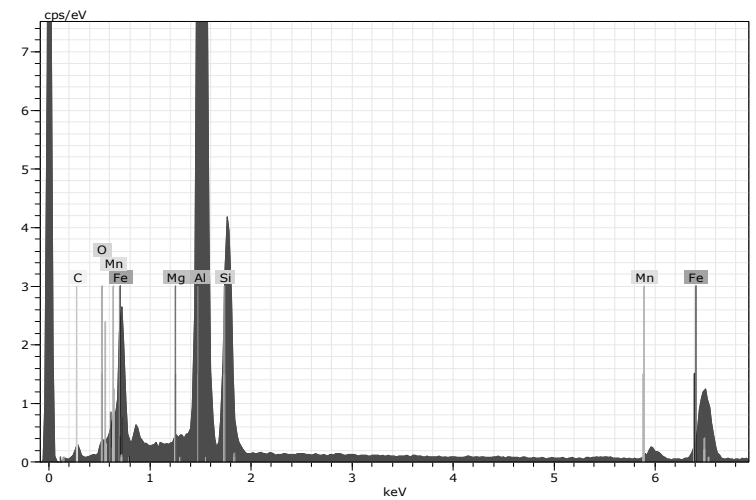

Fig. 15 Spectrum of analyzed chemical elements of the area EDS analysis (area in Fig. 14)

The surface EDS analysis of bright glossy surfaces (Fig. 14) shows the presence of $\mathrm{Al}, \mathrm{Fe}$ and $\mathrm{Si}$, where the stoichiometric ratio can be inferred that these are fragile intermetallic phases of type $\mathrm{Al}_{5} \mathrm{FeSi}$. A large number of these fragile intermetallic phases at the fracture area initiate their fission breakdown and cause total cracking and crack propagation over the entire cross section of the casting. The presence of oxygen and carbon is related to surface oxidation and partial contamination of the fracture area.

Tab. 4 Quantification of field EDS analysis results

\begin{tabular}{|c|c|c|c|c|c|}
\hline Element & Series & unn. C [wt. \%] & norm. C [wt.\%] & Atom. C [at. \%] & (3 Sigma) [wt. \%] \\
\hline Aluminium & K-series & 40.76 & 61.52 & 59.04 & 5.93 \\
\hline Iron & K-series & 8.79 & 13.27 & 6.15 & 0.85 \\
\hline Silicon & K-series & 6.60 & 9.95 & 9.18 & 0.95 \\
\hline Manganese & K-series & 2.44 & 3.69 & 1.74 & 0.33 \\
\hline Oxygen & K-series & 1.32 & 1.99 & 3.21 & 1.14 \\
\hline Carbon & K-series & 6.35 & 9.59 & 20.68 & 4.88 \\
\hline & Total: & 66.26 & 100.00 & 100.00 & \\
\hline
\end{tabular}

\section{Location № 3}

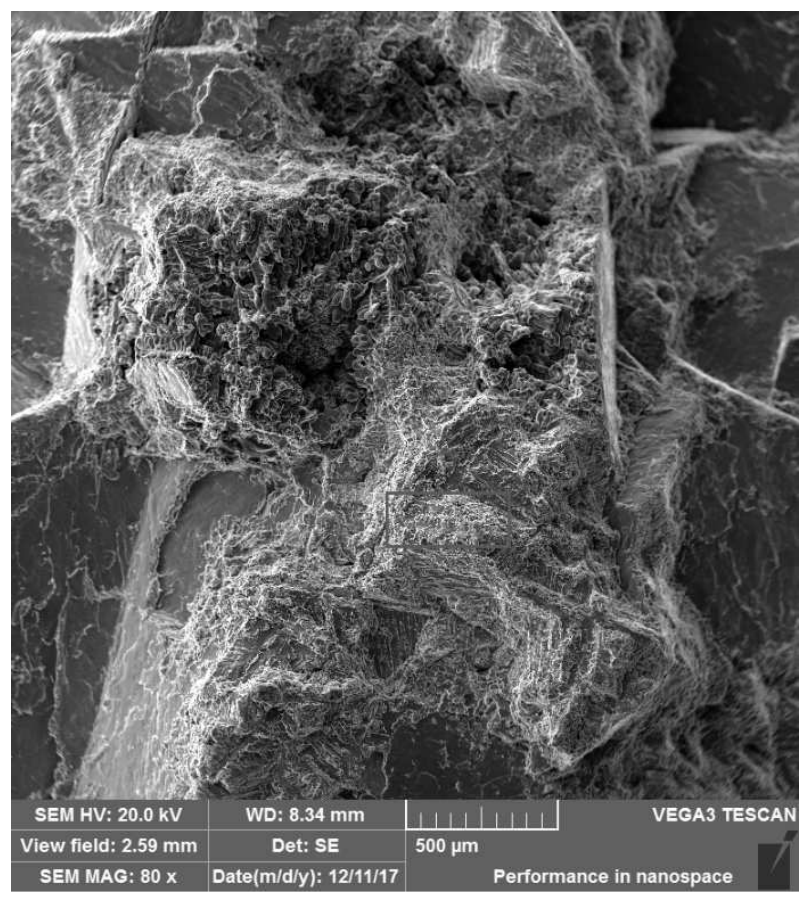

Fig. 16 Surface analysis of the sample

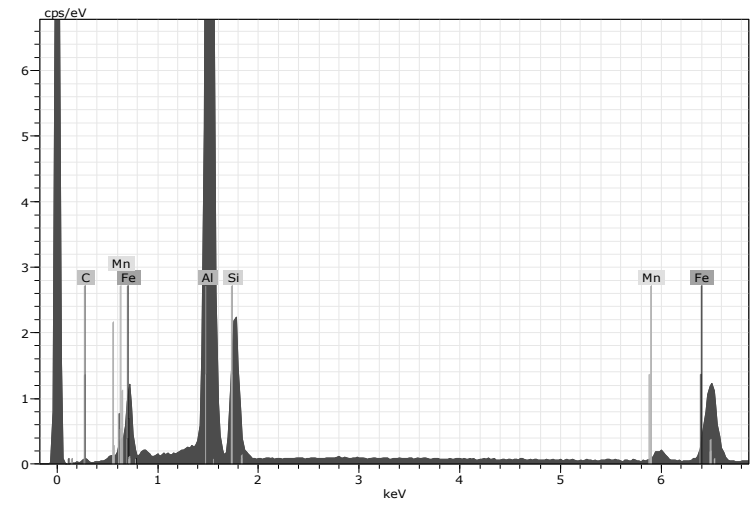

Fig. 17 Spectrum of analyzed chemical elements of the area EDS analysis (area in Fig. 16)

The surface EDS analysis of light glossy surfaces (Fig.18) of the fracture break on the fracture surface shows the presence of $\mathrm{Al}, \mathrm{Fe}$ and $\mathrm{Si}$, where the stoichiometric ratio can be inferred that these are fragile intermetallic phases of type $\mathrm{Al}_{5} \mathrm{FeSi}$. A large number of these fragile intermetallic phases at the fracture area initiate its fission breakdown and cause total cracking and cracking across the entire cross section of the cast. The presence of oxygen and carbon is related to surface oxidation and partial contamination of the fracture area. 
Tab. 5 Quantification of field EDS analysis results

\begin{tabular}{|c|c|c|c|c|c|}
\hline Element & Series & unn. C [wt. \%] & norm. C [wt.\%] & Atom. C [at. \%] & (3 Sigma) [wt. \%] \\
\hline Aluminium & K-series & 42.60 & 58.07 & 48.65 & 6.21 \\
\hline Iron & K-series & 5.10 & 6.95 & 2.81 & 0.60 \\
\hline Silicon & K-series & 7.89 & 10.75 & 8.66 & 1.14 \\
\hline Manganese & K-series & 2.02 & 2.75 & 1.13 & 0.33 \\
\hline Oxygen & K-series & 2.62 & 3.58 & 5.05 & 2.18 \\
\hline Carbon & K-series & 13.14 & 17.91 & 33.70 & 9.44 \\
\hline & Total: & 73.36 & 100.00 & 100.00 & \\
\hline
\end{tabular}

\section{Location № 4}

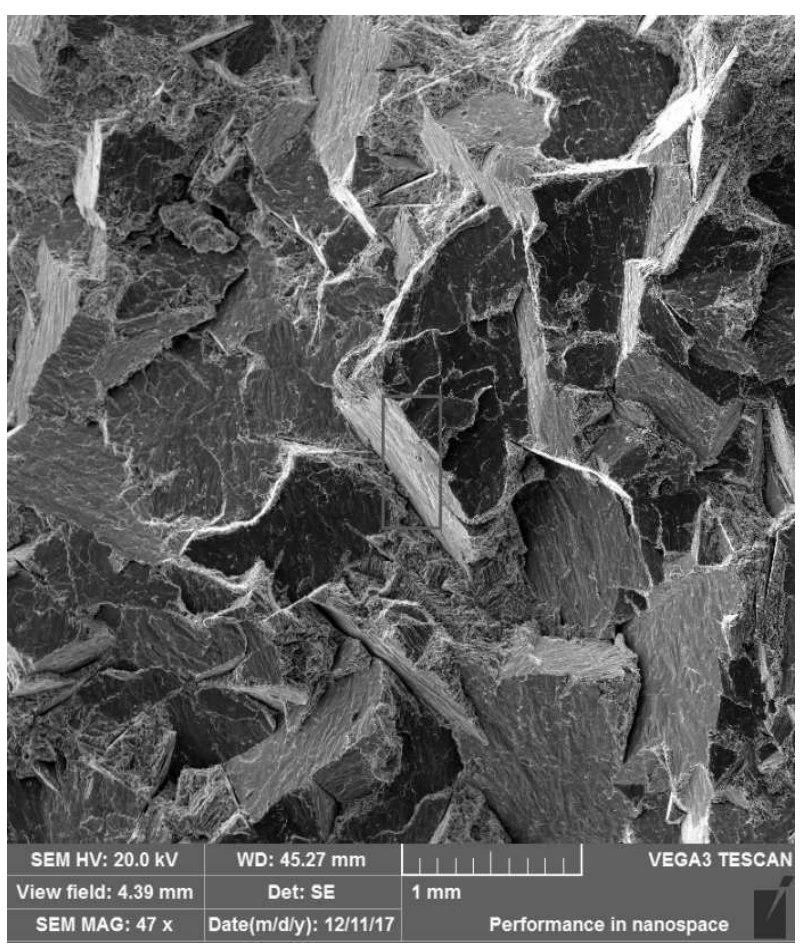

Fig. 18 Surface analysis of the sample

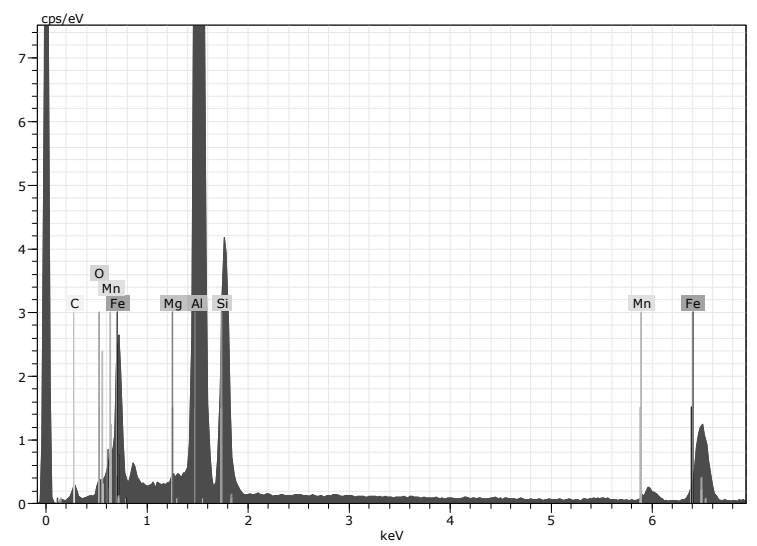

Fig. 19 Spectrum of analyzed chemical elements of the area EDS analysis (area in Fig. 18)

The surface EDS analysis of light glossy surfaces (Fig.18) of the fracture break on the fracture surface shows the presence of $\mathrm{Al}, \mathrm{Fe}$ and $\mathrm{Si}$, where the stoichiometric ratio can be inferred that these are fragile intermetallic phases of type $\mathrm{Al}_{5} \mathrm{FeSi}$. A large number of these fragile intermetallic phases at the fracture area initiate its fission breakdown and cause total cracking and cracking across the entire cross section of the cast. The presence of oxygen and carbon is related to surface oxidation and partial contamination of the fracture area.

Tab. 6 Quantification of field EDS analysis results

\begin{tabular}{|c|c|c|c|c|c|}
\hline Element & Series & unn. C [wt. \%) & norm. C [wt.\%] & Atom. C [at. \%] & (3 Sigma) [wt. \%] \\
\hline Aluminium & K-series & 43.50 & 56.88 & 50.65 & 6.35 \\
\hline Iron & K-series & 7.37 & 9.64 & 4.15 & 0.80 \\
\hline Silicon & K-series & 9.84 & 12.87 & 11.01 & 1.40 \\
\hline Magnesium & K-series & 0.43 & 0.56 & 0.56 & 0.18 \\
\hline Manganese & K-series & 2.10 & 2.74 & 1.20 & 0.34 \\
\hline Oxygen & K-series & 3.32 & 4.34 & 6.52 & 2.60 \\
\hline Carbon & K-series & 9.91 & 12.96 & 25.92 & 8.12 \\
\hline & Total: & 76.48 & 100.00 & 100.00 & \\
\hline
\end{tabular}

\section{Conclusions}

The spectral chemical analysis of the casting has a high iron content (up to $2.32 \mathrm{wt} . \%$ ), which is inadmissible in view of its negative influence on the mechanical and chemical properties of the alloy (flexibility, ductility and strength). The required alloy permits the iron content, which is the major impurity element, to be max. $0.7 \mathrm{wt}$. $\%$, since from the point of view of conducted research and literary sources with an iron content above $0.6-0.7 \mathrm{wt}$. $\%$ (in the absence of $\mathrm{Mn}$ ), brittle inter-metallic phases of the $\mathrm{Al}_{5} \mathrm{FeSi}$ type occur. The surface EDS analysis of bright glossy surfaces in the fracture area at the fracture surface shows the presence of $\mathrm{Al}, \mathrm{Fe}$ and $\mathrm{Si}$, where the stoichiometric ratio can be said to be brittle intermetallic phases of type $\mathrm{Al}_{5} \mathrm{FeSi}$. A large number of these fragile intermetallic phases on the fracture area initiate their cleavege and cause total cracking and crack propagation over the entire cross section of the casting. The presence of oxygen and carbon is related to surface oxidation and partial contamination of the fracture area. The microstructure examination only confirms the results from the fracture analysis where, due to the high iron content, the coarse intermetallic phases of the $\mathrm{Al}_{5} \mathrm{FeSi}$ type of approximately 
$160-400 \mu \mathrm{m}$ are apparent in the structure. Part of the intermetallic phases of the $\mathrm{Al}_{5} \mathrm{FeSi}$ type is also excluded in the form of irregular shape-like compact formations. In the microstructure there are branched intermetallic phases of AlFeSiMn of Chinese script type in size from 100 to $300 \mu \mathrm{m}$. The fragmentary microstructure of the refraction line largely in the fracture area shows fractal fracture of brittle intermetallic phases of the $\mathrm{Al}_{5} \mathrm{FeSi}$ type that initiate material fracture. From all the analyzes and fractographic investigations carried out, it can be stated that the initiator of crack insertion and subsequent cracking of the casting under load is the high content of coarse needlelike fracture intermetallic phase of $\mathrm{Al}_{5} \mathrm{FeSi}$ type on the fracture area (over 20\%), which are subject to cleavage. The high iron content was due to the dissolution of the cast iron ascension tube by low-pressure casting.

\section{References}

[1] MICHNA, Š. (2005). Encyklopedie hliniku. 1. vydání, Prešov, SR: Adin s. r. o.

[2] MICHNA, Š., NÁPRSTKOVÁ, N. (2012). Tvářní. Ústí nad Labem.

[3] BOlibRUCHOVÁ, D., TILlOVÁ, E. (2005). Zlievarenské zliatiny Al-Si. Žilina: EDIS - vydavatel'stvo ŽU.

[4] MONDOLFO, L., F. (1979). Aluminium Alloys, Structure and Properties. Butterworths, London.

[5] NOVÁ, K., Novák, P., ARZEL, A., PRŮŠ, F. (2018). Alloying of Fe-Al-Si Alloys by Nickel and Titanium. In Manufacturing Technology, Vol. 18, No. 4, pp. 645-649.
[6] ŠVEC, M., VODIČKOVÁ, V., KELLER, V., HANU, P. (2018). The Effect of Chromium Addition and Heat Treatment on Phase Composition of Cast FeAlSi Alloys. In Manufacturing Technology, Vol. 18, No. 6, pp. 1029-1033.

[7] NOVAKOVA, I., MORAVEC, J., KEJZLAR, P. (2017). Metallurgy of the Aluminium Alloys for High-Pressure Die Casting. In Manufacturing Technology, Vol. 17, No. 5, pp. 804-811.

[8] BORKO, K., TIllová, E., CHAlupovÁ, M. (2016). The Impact of Sr Content on Fe - Intermetallic Phase's Morphology Changes in Alloy AlSil0MgMn. In Manufacturing Technology, Vol. 16, No. 1, pp. 20-24.

[9] HREN, I., SVOBODOVA, J. (2018). Fractographic Analysis of Strontium-Modified Al-Si Alloy. In Manufacturing Technology, Vol. 18, No. 6, pp. 900-905.

[10] ŠKOLÁKOVÁ, A., NOVÁK, P., SALVET, P. (2016). Influence of Elements with High Affinity to Oxygen on Microstructure and Phase Composition of Ni-Ti Alloy. In Manufacturing Technology, Vol.16, No. 4., pp. 808-814.

[11] MICHNA, Š., NOVÁ. I. (2008). Technologie a zpracováni kovových materiálì, Prešov, ADIN s.r.o.

[12] SVOBOdOVA, J., LUKÁČ, I. (2018). Degradation Structures of the Steels Applied in Energetics. In Manufacturing Technology, Vol. 18, No. 5, pp. 846-850. 